\title{
El misterio del poder en el pensamiento de N.A. Berdyaev: Un estudio literario y filosófico
}

\section{The theme of the mystery of power in the thought of N.A. Berdyaev: A Literary and Philosophical Study}

\author{
Aleksandr V. Usachev ${ }^{1 \mathrm{a}}$ \\ Bunin Yelets State University, Yelets, Russia ${ }^{1}$ \\ iD Orcid ID: https://orcid.org/0000-0002-6150-20501
}

Recibido: 26 de octubre de 2020

Aceptado: 08 de enero de 2021

\begin{abstract}
Resumen
El propósito de este artículo es replantear la cuestión del poder y su esencia en el contexto de cómo lo ve la filosofía religiosa rusa, en este caso, N. A. Berdyaev. Sus reflexiones cobran relevancia porque plantea el problema en un sentido universal, vinculándolo con la esencia del hombre y los hechos históricos que lo rodean. La ontología histórica se revela en la filosofía del pensador ruso como un misterio infinito, cuyas definiciones racionales son muy difíciles. La metodología de este trabajo está tomada de los trabajos del programa sobre la historia de la filosofía rusa de V. V. Zenkovsky y N. O. Lossky y consiste en crear una base comparativa para comparar los principales conceptos de poder en la filosofía occidental y la filosofía rusa. Incluso un análisis aproximado muestra que el gobierno elude el discurso y evita las definiciones racionales, de lo contrario sería posible explicar la revolución en Rusia por su carácter fundamental. El material del artículo puede ser utilizado en estudios sociales y antropológicos del poder, lo que aumenta y extiende su influencia incluso a las relaciones más simples pero en lugar de reducirla. Los creadores de nuevas épocas siempre enfrentan un nuevo tipo de responsabilidad en el sentido de que son responsables ante las generaciones vivas de cómo usan el poder y si es para bien o para mal.
\end{abstract}

Palabras clave: Filosofía, poder, deber moral, personalismo, existencialismo, filosofía de la historia, revolución, sociedad.

\begin{abstract}
The purpose of this article is to raise the question of power and its essence again in the context of how Russian religious philosophy, in this case, N. A. Berdyaev, sees it. The methodology of this work is taken from the program works on the history of Russian philosophy by V. V. Zenkovsky and N. O. Lossky, and consists in creating a comparative basis for comparing the main concepts of power in Western philosophy and Russian philosophy. Even a rough analysis shows that the government eludes discourse and eschews rational definitions, otherwise it
\end{abstract}


would be possible to explain the revolution in Russia by its fundamental character. The material of the article can be used in social and anthropological studies of power, which increases and extends its influence even to the simplest relationships but rather than reducing it. The creators of new eras always face a new kind of responsibility in the sense that they are responsible to the living generations for how they use power and whether it is for good or for harm.

Keywords: Philosophy, power, moral duty, personalism, existentialism, philosophy of history, revolution, society.

\section{Introduction}

To think over the question of power in Russian philosophy in general and in Berdyaev's philosophy in particular always means to prefer the religious-philosophical approach to the instrumental, "anatomical" one. It is less detailed, not so much equipped with historical material, and, most importantly, it is absolutely impossible for the use in the technological sense, if one decides to identify certain power procedures that accompany our life, affect it with such significant force that one has to think about them willy-nilly (Berdyaev, 2009).

The lack of a practical result in studying and analyzing power in Russian philosophy leads to the conclusion that the very freedom to talk about it outside the framework of generally accepted norms of the positivist sense clearly demonstrates the incomplete grasping of the power of thinking in the Russian religious and philosophical tradition by this range of problems. This seems to be caused by a combination of several circumstances. (Zenkovsky, 2014) One of them is connected with the fact that the world is perceived as a single organic whole, in which one manifestation is not isolated from others.

The dominance of one component is mediated by many other elements of the whole. In addition, philosophy has several roots rather than only one, and all of its originality is determined by this. Therefore, it is quite natural to merge such features as religiosity and realism (Berdyaev, 2016). These features are included neither in axioms nor in the body of arguments in favor of the originality of Russian philosophical knowledge, but they represent a kind of ontological prescription.

The famous Russian philosopher Fr. V. Zenkovsky (2014), among other characteristic features, drew attention to the history-sophical nature of Russian thought, and this is the most interesting observation that corresponds to the essence of questioning this text. The point is that Russian philosophy goes from the particular to the general. German Philosophy is otherwise directed from the general to the particular. This is how Russian philosophy developed in the first quarter of the 20th century. In this short period, Russia was beset by two wars and three revolutions. Therefore, it is rather difficult to imagine that philosophical and historical thinking can be initiated speculatively, as opposed to origination from the historical practice itself.

German classical thought proceeds from the general - the historical dynamics of the concept and the phenomenon of freedom in the world history - to the concretization of the main 
predicates of the particular - the German spirit. The Russian construction of thought starts from a fateful private event (a revolution, a war in Russia - The Fate of Russia by N. Berdyaev, Time is a Slavophile by V. Ern, The Path of Spiritual Renewal by I. Ilyin) (Zenkovsky, 2014) and goes back to generalizations of the highest order concerning the entire world, i.e., to the general. The category of unitotality is primarily in the status of the general; this category is used to consider the single transcendental source of all that exists, and in the dynamic sense, the fate of all that exists (Berdyaev, 2009).

Russian analytics of power concerns the authenticity of Russia's historical path. However, this is no longer the reasoning of the Slavophiles and Westernizers, but rather an attempt to navigate the restless field of historical practice at the beginning of the 20th century. It is little wonder that the revolution was the starting point for the most intense study of the question of power. Indeed, the stream of theoretical and practical explication of fundamental definitions of power concerned everyone.

The left wing of the Russian intelligentsia did not solve the issue of the theory of power but thought how to seize completely it aiming to achieve certain speculative projects that were a syncretic product of the 19th century's social thought and the Russian form of interpreting Marx's economic materialism (Inishev, 2018).

The seizure of power was considered a certain privilege of the selected people thinking in an orthodox way. A case is known when Berdyaev was in exile and polemicized a lot with Lunacharsky and Bogdanov. After listening to his arguments, they treated them with a fair amount of irony and simply persuaded him to leave the ranks of Marxism, because, they said, Berdyaev was a hopeless idealist (Shkoda, 2000).

\section{Methodology}

The article is based on the materials of N. Berdyaev's own books, as well as on the ideas that accompany the discussion of his main theories that underlie the study of power as a spiritual and social phenomenon. Power blurredness in gestures, army commands, hospital regimes, school discipline, i.e., in all that M. Foucault wrote about in such detail, is one of the signs of its absolute secularization and instrumentalization.

The article notes that the theory of N. Berdyaev correlates with the concepts of power, both modern and historical. The author examines the phenomenon of power not only during the period of revolutionary changes, but also in ancient times, when power was not yet understood as a phenomenon of social existence. Basically, this is phenomenality, rather than the essential rootedness of power. In this form, power does not guarantee a stable form of preserving traditions, and the initial will to know the source. In Germany, such a source was interpreted in the form of ancient Greece (Heidegger, 2013), and philosophy (Husserl, 2015) 
The study uses a comparative method that allows you to compare different approaches and materials that relate to the assertion of power in the social system of a stable and rebellious time. Such a will for something primordial, which has yet disintegrated neither in the objective world nor in the subjectivity of the human mind into transcendental and immanent planes, allows the philosopher to carry out discourses about the primordial sources of life, deriving explicit designate of phenomenal power, formal and yet fateful subordination. Such a burden of power, in which everything negative is projected, especially as a result of absolutization, is science: "its spheres are the premises of a hospital [an obvious echo with M. Foucault, who wrote much later-A.U] the world that fell ill from sin and is subject to the law of decay obeying the law of necessity" (Berdyaev, 2003).

The materials used in the article indicate that N. Berdyaev's conclusions have a research perspective, as well as echoes in modern concepts of power, which today play the role of fundamental ones. Even here, power reveals itself as a complicated vector for philosophical thought thinking through and actualizing. It is an obvious sign of the world of necessity and, therefore, we can talk about its laws and subordination in skillful human hands to be used for certain purposes. On the other hand, this is its transcendental character. Moreover, this is Berdyaev's main theme, to which he will get closer and closer throughout his entire career (Grober, 2016).

Based on the materials and methods that are implemented in the article, it is safe to say that power can be effectively investigated, and conclusions can be drawn about its sources and prospects. The philosopher will often, from time to time, recollect the explanation of Christ's teachings by St. Paul the Apostle about the necessity to render to Caesar the things that are Caesar's; and to God the things that are God's, and in no case should Caesar be rendered the God's things, not to strengthen and not provoke the strengthening and constitution of the human-divine kingdom, speaking in the language of Russian philosophy. The Kingdom of God on earth is perhaps the most striking project of power absolutization (Bodea, 2019). Despite the abundance of literature, N.A. Berdyaev's creative activities have been little studied in several key characteristics of his work. The question of power is just like that. It combines such significant indicators as the problem of personality, the essence of social transformations, the possibility with a certain guarantee to refer to the future. The difficulty of analyzing Berdyaev's creativity lies in the fact that having paid attention to some detail of reality, he usually gives it a figurative definition, which is combined with philosophy as a rational science only in part.

On the other hand, it can be said unequivocally that the penetration into the essence of philosophical problems by the Russian philosopher is almost the most thorough of all who dealt with the problem of power. Berdyaev relies not only on the works of philosophers but also on literary works, which means that his approach is based on a wide cultural context, which is a promising feature of his reflections and can be turned into new research on the theme of power. 


\section{Results}

For Berdyaev, religious ontology is a field of questioning that is much more promising than identifying and exposing the mistakes made by a certain regime, although the philosopher addresses this side of the issue as well. But here he appears most often as an intellectual and a citizen of a lost state, and at the same time of the worldview, its pre-revolutionary image in Russia.

As a theoretician, to state a simple understanding by activists of some simple and effective technique of governing and suppression does not at all mean solving the problem, and even less finding a key to the mystery. It is in the religious mainstream that he finds several answers that contain a non-technological algorithm for an approach and a preliminary solution.

The first manifestation of the religious approach is to presume the historically established Russian aristocracy as a moral force that has imperious class superiority but does not use it utilitarianly, being burdened with this superiority, and, therefore, accepting power as a gift, rather than a conquest, not a man-made structure. A unique effect of beneficence arises, which is a consequence of the fact that power is not considered as an end in itself.

The second theme is traditionally Christian. Power is regarded as a modification of slavery before God. Here Berdyaev touches on the classical formulation of Hegel's question of "master and slave", but in comparison to him, he moves away from interpreting it in the key of dialectical logic, directing the talk into the terminology of theological or religious-philosophical type, deriving the mediation of everything that happens by the theophanic process as the determining factors, and introducing the categories of Providence and the will of God.

These categories are not an escape from the problem, but its new articulation. Referring to the language of N. Lossky's philosophy, we are talking about the general mediation by the whole (the Absolute) of any attributes of being in any modifications: social, spiritual, personalistic, etc. (Lossky, 1991) The relationship of one to another contains a whole, in whatever hierarchy and binary descriptions it is fixed: the best/the worst, the advanced/the backward, the higher/the lower, etc. (Frank, 1990)

Berdyaev did not pose the theoretical question of power in the context of contemporary events. This was consistent with his vision of the role and place of the philosopher in the world. Untimeliness is the quality that is inherent in the truly philosophizing person. Berdyaev does not explain what is the meaning of "not in the right time" - in the future or in the past (Berdyaev, 2009a).

Nevertheless, the modus of the present, grasped by calculating thinking, anthropological crisis, fashion, current tasks is clearly marked. Essentially is something that is not in its time, which is limited only by worldly relations. Consequently, the essential formulation of the question of power, the disclosure of its transcendental meaning is a matter of the past. Another 

way is possible - prophetic intuitions and the interpretation of the paradigm of the three religious' stages of civilization - the era of law, the era of redemption, and the era of creativity.

Berdyaev was confident in the correctness of his assertion about such historical dynamics, if, of course, he did not confine himself to the definitions of sociological theory and practice, but was involved in thinking through the aspects of the spiritual transformation of contemporary reality, which has not only clearly expressed signs of crisis, but also reveals the potential of future decisions. This was the construction of thought, which, for example, $\mathrm{M}$. Heidegger illustrated with a quote from Friedrich Hölderlin: "But where the danger is, also grows the saving power" (Heidegger, 2013). The difference, perhaps, is only in the fact that the Russian philosopher did not transfer the trust of the logic of the development and salvation of society to the objective force of dialectics.

He trusted in and relied on personal spiritual mobilization, which would certainly arise in the conditions of the utmost obviousness of the contradictions and conflicts of civilization in the first half of the 20th century. Because, according to the philosopher, the creative era has already gained strength and has an inevitable, providential nature, the image of power also contains a tendency to amend.

This amendment is associated with the strengthening of a religious component, i.e., recognition of the essence of power rather in a single source with other practical methods of regulation and control, transformation, and overcoming of crisis phenomena that are fateful for society than in phenomenal implementation. Technology must be complemented with religiously understood creativity and the realization of personal freedom. It is these circumstances that are at the same time the criteria for getting out of the tightness of the pernicious manifestations and consequences of the civilization process in the transformation of classical values.

For the other hand, it is rather difficult to assess the actual philosophical concepts from the viewpoint of their executability. But at the same time, qualifying everything that has been mentioned above only as a utopian project, as features of a response to the irrepressible gains of modernism, as romanticization and softening of the discourses about power to give them a more humanitarian tone, is apparently also wrong. Berdyaev formulated fairly accurate ideas and their meaning is clear. This meaning is primary rather than derivative, since it clarifies the problem of the origin, and expresses the essential peculiarities that outline the area of search for answers to the main questions.

In the introduction to the book On Slavery and Human Freedom $(1939 ; 2003)$, he wrote that both the right and the left, in general, the politicization of all questions of being, was repugnant to him. Only a synthesis is possible from such a system of views in the key of Hegel's dialectics, uniting viable tendencies of both. If one overcomes the limitations of Hegel's system, the clash of its completeness with the infinite potential of dialectical development, with time 

of society.

Therefore, the Russian philosopher insists on a fundamentally different basis for solving the main questions posed in view of the change in the image and quality of power. Berdyaev writes: "The new religious consciousness of the Third Testament will expose the lies of the old theocracies that have confused the human with the Divine, and the new democracies that deified the human, and will lead to a new and eternal theocracy in which the power will be truly Divine, and a person who has resigned oneself to this power will be raised to the Divine height" (Berdyaev, 2003).

In case of failure to notice that an idea, thought, talent, genius, art can have power, and not in a figurative sense, but in literally, that is, to influence the character, behavior, selfperception of a person, the mystery of power will remain "locked behind the seven seals" (Berdyaev, 2009a) even at the level of resolution of the issue which is accessible to a person in cognitive practices. By limiting the meaning and content of power, a person removes oneself from its correct perception and, ultimately, its use. Not to limit, but to expand the possibilities of cognition - this task can be seen in the efforts of the Russian thinker. And the most important thing in his approach is that he defined the concrete outlines of the unresolved issue of power. For this, it is necessary to comprehend the personalistic attitudes of his thinking.

\section{Discussion}

It is a rather banal statement that man is a contradictory being. But it also allows for effective development of the beginning of a concept proceeding from Hegel's ideas about the master and the slave. Their interdependence on each other in a single social whole is a paradigmatic conclusion. Nevertheless, this conclusion makes it possible for Berdyaev to find an intellectual space for searching for new answers. If everything that was subjected to his criticism is confined in dialectics and dynamics of the master-slave relationship, all instrumental issues are absolutely not suitable for analytics and thinking over the essence of power for the "free".

This is where the point of collision and deformation of modernist discourses about power as a transformative force that constructs existence is located. "In the slavery world of objectivity, violence is considered a force manifested by force... Force in a deeper sense means possession of what it is directed at, rather than domination, in which externality is always preserved, but a persuasive, internally conquering connection" (Berdyaev, 2003). The philosopher thereby makes it clear that through external influence on existence, through even a filigree development of the instrumental side of power, a breakthrough to being is impossible.

Only it determines the essential personal principle, which alone is capable of transforming the world, not for better or worse, but under Providence and the sovereign plan of 

the historical in the depths of the eternal. It is precisely in Berdyaev's philosophy that a subtle restraint from progressive aspirations and modernist pseudoscientific dreams is very clearly visible. Christian consciousness, based on the belief in suffering God, in resurrection and redemption, does not allow the future to be equated with unconditional improvement in the civilizational sense, i.e., in the incarnation and steady growth of the comfort and adaptation of the Existence to man, rather than man to the truth of the Existence. The will, realized in history and the actions of power, can be distributed and objectified in a way that does not at all fit the external parameters of well-being.

Not only goodness in the material world can be considered a movement forward. "The world is bad not because it contains matter, but because it is not free, it is enslaved" (Berdyaev, 2003). In other words, almost entire philosophy, without exception, solves the question of power and subordination within the framework of the classical formulation of the question. The problem is to settle this question not for the slave's temporary feeling of being free in some situations, and not in the context of the master's slavish subordination to his whims, which manifest themselves from time to time or constantly. The problem is to solve the whole set of ambiguities with the question of power and force for the "free" person, for the subject.

Thereby, at least, a man can get out of the vicious circle of constant return to the category of necessity, which is typical for the natural, physical world, and, consequently, for the temptation of positivist simplification of the true complexity of this philosophical topic. Why should we decide the question of the unfreedom of the unfree, either in the role of a master or in the role of a slave? We should solve the issue of freedom of the free person, of the force of power in the direct existence of the personality, outside of sociological qualifications and projects. This thought is evidently seen in Berdyaev's interrogation, though the creative nature of a personality's being in freedom also presupposes rather unpredictable interpretations of power and its source: "We are free, but any gust of wind will force us and attract..." (Rilke, 2013).

A close friend and eternal opponent of Berdyaev Lev Shestov (1993) wrote on the pages of one of his books that a truly philosophical formulation of the question asserts itself when we regret rather than in case we are lamenting the death of the philosopher himself, his unique personality about the ideas, for example, those of Plato, which leave our world. It is precisely this construction of thought that makes it possible to speak of entering the set of problems of religious and philosophical anthropology. As a result of such reasoning, Berdyaev always formulated friendly resolutions in his letters that Shestov lacks an Eastern Christian perception of the environment (Shestov, 1993). Abstracting the philosopher's personality from his ideology is an artificial technique, although it clearly presents the peculiarities of the philosophical view. 
Shestov was also right because even now we are deeply peering into the "close horizons" of the space of Berdyaev's thoughts as a philosopher, counting the decades since his birth: a man was born into the world. A whole philosophical school entered Russian thought, which, unfortunately, got its development not in Russia, but in America and France, and entered the intellectual palette of world philosophy under the name of "personalism" - the philosophy of personality (Shestov, 2009). But it is not true to think that Berdyaev also stayed away from the truth. Is it possible to seriously refute the fact that precisely ideas, transmitting sense-bearing constructions through the centuries, survive much more successfully than their authors, enabling some of their contemporaries to think that they are independent in choosing a historical or scientific strategy?

Who today does not know that going back to the past is an even greater utopia than implementing bright projects for the future? This was noticed by Berdyaev, who pointed out simultaneously that with all his monarchical and Orthodox views, he cannot resign himself to with the dream of a complete reconstruction of pre-revolutionary antiquity because that it had once already created the prerequisites for a revolution, for a bloody and not yet fully comprehended event in the contemporary history of Russia (Gaisin, 2018). It is not uncommon that here and there a sad note sounds that the present time is characterized by the fact that utopias come true, but when they are implemented, people do not find what they want, with all the formal authenticity of what they have done in mobile historical creativity. And this is Berdyaev's idea (Berdyaev, 2002).

In the 1920s, the theme of "atomization" of modern society, individualization of social, political, and humanitarian practices was discussed at the Free Academy of Spiritual Culture. The era of double thoughts, double morality, unbalanced spiritual being, regression of the personal qualities of a person who refused to recognize a super-individual being - all these predicates of the current minute of existence were sudden clarifications of one person. He was a professor of philosophy at the independently organized Academy for about two years, until the government of the new Russia sent him on a philosophical steamer to the "other shores", to Germany. In the texts of this period, he spoke about the change in the legitimation principles of the entire hierarchy of values and the ways of their substantiation.

All of the above facts, humanity would read and take into consideration in twenty years from Jung who revealed the phenomenon of regression, and fifty years later, in the texts of postmodern ideologists: Lacan, Deleuze, Guattari, and others. Psychoanalysts and postmodernists recorded the reality of their times (Inishev, 2018). They did not repeat the thoughts of the Russian thinker. If we consider them as successors, much will remain unresolved and inexplicable. This way of posing the question does not stand up to criticism. Intuitions and sensations of being have always come from the East, rather than theories or formulations. 
Otherwise, the acuteness of the contradictions between spiritual knowledge and rational implementation of being would never have made itself felt.

However, precisely this acuteness became in many ways culture forming for Russia and allowed the birth of many predictions and warnings about the social fate of Europe and the whole world. All, one way or another, say about the same thing, at least on a principled level and in the same civilizational field. With his entire creative work Berdyaev, carried out the main, in his opinion, the function of philosophy - the prophetic one. He rather predicted than deduced. He took cues from "living contemplations of the spirit", and did not claim the exclusiveness of his consideration and the unambiguous authorship of his discoveries in the ranks of the world philosophical beau monde. Such a theme confidently inscribed his reflections in the common European space, giving an expanded interpretation of the problem of man, the ways of his self-determination in such a form of modern life, where the main cornerstones of culture have been rearranged from their places to others that are not at all suitable for this.

"The will to transform culture into being," wrote the thinker, "creates a crisis of culture. It is known to the greatest people of culture, and through them, a crisis occurs. The will to the latter, a truly ontological will, cannot be content with separate, autonomous spheres of culture, it is directed toward unity and integrity... In our era, there is no visible and recognized spiritual center, the center of the mental life of the era. The university ceased to be such a center; it has no spiritual authority. The rulers of the thoughts of our era are not academicians. Neither academic philosophy nor academic art has any vital influence (Berdyaev, 2002).

Like most Russian philosophers of that time, Berdyaev went through the crucible of two main temptations, which illusorily promised a solution to many social problems that were urgent by that time. The first was related to Marxism. The second concerned the political movement "New Religious Consciousness" (Zenkovsky, 2014). The first was a life-changing temptation. The second tried to reach the line of active dialogue with the Russian Orthodox Church.He did not become an orthodox Marxist. Moreover, the exile to Vologda was not a bitter trial for him; rather it was tough and decisive in choosing his fate, in determining his talent.

For the future master of thought, it turned into an interrupted education at the university, persistent doubt about the effectiveness of a rebellious form of social activity. Nevertheless, precisely this concurrence of events allowed the philosopher to move from the romantic mastering of Marx's theory and maximalist student demonstrations with appropriate slogans about social equality to real scientific disputes about the nature and objectives of the most popular interpretation of sociality at that time. "And the disputes in Vologda were hot. "Democracy" headed by Bogdanov and Lunacharsky, as expected, was squeezing out the "aristocracy" (Berdyaev, Savinkov, Remizov), inclined towards idealism and metaphysics. 
Beaten on earth based on science and logic, idealists went to Heaven, to the realm of the transcendent (Shkoda, 2000).

Precisely at that time, it became clear that the pathos of metamorphosis and revolutionary changes does not at all coexist with a gradual and real shift in the quality of power. On the one hand, "power is rather an obligation than a right, and power is only correct when it is exercised in the name of God, in the name of righteousness rather than in the name of its own" (Berdyaev, 2003). On the other hand, "a revolution is never what it ought to be, for there is no proper revolution and a revolution cannot be oughtness" (Berdyaev, 2003). The role of the Russian Revolution in the history of Russia will never exhaust its meanings and senses. However, the semantics of this historical event is not confined only to the possibility of reasoning about how the socio-economic line of development of our country would have advanced with any other forms of historical creativity. One thing cannot be denied. Russian communism gave rise to the richest tradition of the philosophy of history, in the depths of which versatile theories and conclusions about the characteristic features of the contemporary era were developed (Astapov, 2019).

Activities in the "New Religious Consciousness" gave a fundamental impetus to Berdyaev's creative work for the formation of philosophical confidence that the dominant scope of problems of our time is associated with man and the main existentials of his presence in the world. Studying this theme, the Russian philosopher expressed many ambiguities.

Since ancient times, ontology has been asking the question of authenticity. The confusion of the avant-garde classes, seized by the modernist ideology, became strongly decisive in this matter. "Long, long time ago, it is high time for you to weaken your movement to the surface and start moving deeper, it is high time to change your mind, to look into the depths of the soul, in which the whole infinity of the world and the infinity of God must truly be revealed.

You need to overcome the isolation of your social well-being, you need to feel the community as an inseparable part of the cosmic whole, you need to recognize the community as an inseparable part and stage of the Divine world order". Further: "Thousands of threads connect the human community, lost at a small point of the immense world whole, with the life of the great cosmos, God's world" (Berdyaev, 2015). There is no doubt that these are very high requirements for the creators of new eras, for new subjects of power. But the price that was revealed to the philosopher's eyes is not at all frivolous.

Any action intended to change the course of being of existence and its structure sets changes as the main goal, reaching a change in consciousness, psychology, and the image of a man. The Age of Enlightenment in Europe, and later - rebellious Russia tried to say in a new way what had been from the ages: "Then God said, 'Let us make mankind in Our image, in Our likeness" (Genesis 1: 26). So, God created mankind in His own image, in the image of God He 

created them; male and female He created them" (Genesis 1:27). Who tried to create at this time? Berdyaev gave a multifaceted definition for such creators. Recognizing the creative nature of meaningful being, the philosopher is inclined to believe that any pretentious action cannot be regarded as creativity, as the creation of a new quality rooted in the depths of the creative spirit.

\section{Conclusion}

"Power" generates many discourses about various subjects of the world givenness, and it requires a scrupulous analysis of its personalistic structure. According to Berdyaev, the mystery of power is associated, primarily, with the mystery of a person who obeys the structures of power. If one answers the question of what exactly is the mystery of power, it will be possible to become acquainted with the greatest of the mysteries of the human person. The revolution showed that a person easily adapts to the new power, which was revolutionary at that time and was responsible for making the world fundamentally new, not repeating the mistakes of the old outgoing period of life. Power on principle disregards the essence of a person and only conditionally satisfies the condition of considering individuality.

The lack of a practical result in studying and analyzing power in Russian philosophy leads to the conclusion that the very freedom to reason on it outside the framework of generally accepted positivist norms clearly demonstrates the incomplete grasping of the power of thinking in the Russian religious and philosophical tradition by the scope of the problem. Russian analytics of power concerns the authenticity of Russia's historical path. However, this is no longer the reasoning of the Slavophiles and Westernizers, but an attempt to navigate in the restless field of historical practice at the beginning of the 20th century. The trend of a certain constructive model of power within the framework of the socio-political problems of that period of Russian history was very clear and resulted in the phenomenon of a double temptation for the main representatives of Russian religious philosophy.

\section{References}

Astapov, S.N. (2019). The contradictory unity of faith and reason in Christian theoretical thought. HTS Teologiese Studies/Theological Studies, 75(4), article ID a5273. DOI: 10.4102/hts.v75i4.5273

Berdyaev N.A. (2015). The Philosophy of Inequality. Mohrsville: Frsj Publications.

Berdyaev, N.A. (2016). The fate of Russia. Mohrsville: Frsj Publications.

Berdyaev, N.A. (2003). An experience of paradoxical ethics. Moscow: AST.

Berdyaev, N.A. (2009a). Spirit and Reality. San Rafael: Semantron Press.

Berdyaev, N.A. (2009). The Meaning of the Creative Act. San Rafael: Semantron Press. 
Bodea, R.-O. (2019). Nikolai Berdyaev's Dialectics of Freedom: In Search for Spiritual Freedom. Open Theology, 5(1), 299-308. DOI: 10.1515/opth-2019-0023

Dendiberia, A.A. (2015). Ideas of N.A. Berdyaev about the state and law. Philosophy of Law, $7,44-53$.

Frank, S.L. (1990). Written works. Moscow: Pravda.

Gaisin, A. (2018). Solovyov's metaphysics between gnosis and theurgy. Religions, 9(11), Article ID 354. DOI: 10.3390/re19110354

Golovanova, N.F., Lomakina, I.S. (2018). Anthropological inconsistencies in educational characteristics: Comparative approach. Prospects of Science and Education, 36(6), 1017. DOI: $10.32744 / p s e .2018 .6 .1$

Grober, E.M., Bodrov, A.A. (2015). Reception of the ideas of NA Berdyaev in modern socioeconomic reality. Scientific-methodical electronic journal Concept, 13, 1476-1480. Retrieved from: http://e-koncept.ru/2015/85296.htm

Grober, E.M. (2016). Berdyaev's principle of communitarianism as the basis for the formation of interethnic unity. Humanities Scientific Researches, 1. Retrieved from: http://human.snauka.ru/2016/01/13708

Heidegger, M. (2013). Being and Time. Hoboken: Malden Blackwell.

Hughes, R.A. (2014). Nikolai Berdyaev's Apophaticism. St Vladimir's Theological Quarterly, $58(2), 441-455$.

Husserl, E. (2015). Logical Investigations. London: London Forgotten Books.

Ilyin, I.A. (2004). Axioms of Religious Experience. Moscow: AST.

Inishev, I. (2018). Heidegger and Russian philosophizing: The productivity of the distance Horizon. Studies in Phenomenology, 7(2), 546-553. DOI: 10.21638/2226-5260-2018-7$2-546-553$

Kiejzik, L. (2018). The beginnings of Berdyaev's critical Marxism (in light of his unpublished correspondence with Kautsky). Vestnik of St Petersburg University. Philosophy and Conflict Studies, 34(2), 177-185 DOI: 10.21638/11701/spbu17.2018.204

Lossky, N.O. (1991). Selected works. Moscow: Pravda.

Malinin, S.A. (2014). I.A. Ilyin - philosopher and essayist. Young Scientist, 15, 417-419. Retrieved from: https://moluch.ru/archive/74/12620/

Malinov, A.V. (2018). Discourse of nature in Gregory Skovoroda's teaching. Revista di Estetica, 67(1), 33-48. DOI: 10.4000/estetica.2559

Malinov, A.V., Kupriyanov, V.A. (2019). Vladimir Lamansky in Saint Petersburg University. Vestnik of Sankt-Peterburg University, History, 64(1), 211-221. DOI: 10.21638/11701/spbu02.2019.112

Marx, K., Engels, F. (2018). German ideology. Berlin: Berlin Henricus. 
Oborsky, A.Y., Chistyakov, A.A., Prokopyev, A.I., Nikolyukin, S.V., Chistyakov, K.A., Tararina, L.I. The national mentality in the history of philosophy (2018).XLinguae, 11(3), 158-165. DOI: 10.18355/XL.2018.11.03.15

Pascal, B. (2019). Thoughts. Norderstedt: Hansebooks GmbH. ISBN: 3337867219

Petkanič, M. (2018). The concept of personality in the work of Russian philosopher Nikolai Alexandrovich Berdyaev (Climax of the personalistic line of Slavic thought). KonstantinoveListy [Constantine's Letters], 11(1), 130-137. DOI: 10.17846/CL.2018.11.1.130-137

Pilipchuk, D.S. (2014). Some features of the philosophy of religion of I. Ilyin. Tambov University Review. Series: Humanities, 4 (132), 40-48. http://journals.tsutmb.ru/go/

Poltoratsky, N.P. (1975). N.A. Berdyaev. Russian religious and philosophical thought of the XX century. Collection of articles edited by N.P. Poltoratsky. Pittsburgh.

Pylaev, M. (2018). Prolegomena to any future religious studies that may appear as Christian religious studies. St. Tikhon's Orthodox University Review. Theology. Philosophy. Religious Studies [VestnikPravoslavnogoSviatoTikhonovskogoGumanitarnogoUniversiteta, Seria I. Bogoslovie, Filosofia, Religiovedenie], 80, 119-126. DOI: 10.15382/sturI201880.119-126

Ricoeur, P. (2007). History and Truth. Evanston: Northwestern University Press.

Rilke, R.M. (2013). Selected poems. Hoboken: Taylor and Francis,

Rojek, P. (2019). God and Cogito: Semen Frank on the ontological argument. Studies in East European Thought, 71(2), 119-140 DOI: 10.1007/s11212-019-09326-5

Shakhnovich, M.M., Tyzhov, A.Y., Popov, D.S. (2019). The Discussion on Stoicism in Russian Thought of the second half of the 19th -early 20th century and the History of the Study of Christianity. BylyeGody, 53(3), 1125-1133. DOI: 10.13187/bg.2019.3.1125

Shestov, L. (2009). Potestasclavium (Power of keys). Milano: Bompiani.

Shkoda, V.V. (2000). About a man who put freedom above God. In Berdyaev, N.A. The fate of Russia. Moscow: EKSMO-Press.

Solovyov, V.S. (1988). Written works in two volumes. Vol.1. Moscow: Mysl.

Solovyov, V.S. (1988). Written works in two volumes. Vol.2. Moscow: Mysl.

Tenace, M. (2019). Faith and Reason: The Cultural and Ecclesial Implications of the Debate according to Vladimir Solovyov. Renewed Life: Journal of Philosophy and Religious Studies, 74(2), 153-160. DOI: 10.31337/oz.74.2.1

Zenkovsky, V.V. (2014). History of Russian philosophy. New York: Routledge. 